\title{
Uji daya antibakteri ekstrak etanol kulit buah manggis (Garcinia mangostana L) terhadap Streptococcus sanguinis ATCC 10556
}

\author{
Dwita Kemala $^{1 *}$, Ina Hendiani ${ }^{1}$, Meike Hemiawati Satari ${ }^{2}$ \\ ${ }^{1}$ Departemen Periodonsia, Fakultas Kedokteran Gigi, Universitas Padjadjaran, Indonesia \\ ${ }^{2}$ Departemen Oral Biologi, Fakultas Kedokteran Gigi, Universitas Padjadjaran, Indonesia \\ *Korespondensi: dwita14001@mail.unpad.ac.id
}

\begin{abstract}
ABSTRAK
Pendahuluan: Pemeliharaan kesehatan gigi dengan cara menyikat gigi dan penggunaan obat kumur dapat mencegah pembentukan biofilm oral yang dipelopori oleh Streptococcus sanguinis. Kulit buah manggis (Garcinia mangostana L.) adalah kulit buah yang telah diketahui memiliki aktifitas antibakteri. tujuan penelitian mengetahui daya anti bakteri ekstrak etanol kulit buah manggis (Garcinia Mangostana L.) terhadap pertumbuhan Streptococcus sanguinis ATCC 10556. Metode: Jenis penelitian ini adalah deskriptif, untuk mengetahui uji daya antibakteri ekstrak etanol kulit buah manggis (Garcinia mangostana L.) pada Streptococcus sanguinis ATCC 10556. Populasi bahan uji penelitian ini adalah kulit buah manggis (Garcinia mangostana L.) yang ada di Kota Bogor. Sampel yang digunakan adalah kulit buah manggis (Garcinia mangostana L.) yang didapat dari kebun budidaya IPB Bogor. Metode uji hambat yang dinilai dengan menggunakan metode disk diffusion. Hasil: Diameter zona hambat paling besar terdapat pada konsentrasi $200.000 \mathrm{ppm}$ dengan diameter rata-rata 12,55 mm, di ikuti dengan konsentrasi $100.000 \mathrm{ppm}$ dengan diameter rata-rata 11,2 mm, kemudian konsentrasi $50.000 \mathrm{ppm}$ dengan diameter rata-rata $10,3 \mathrm{~mm}$, selanjutnya konsentrasi $20.000 \mathrm{ppm}$ dengan konsentrasi rata-rata 10,05 mm, kosentrasi $10.000 \mathrm{ppm}$ dengan diameter rata-rata 8,2 mm, konsentrasi 2.000 ppm dengan diameter rata-rata 7,1 $\mathrm{mm}$ dan diameter zona hambat paling kecil terdapat pada konsentrasi 1.000 ppm dengan diameter 6,9 mm. Simpulan: Ekstrak etanol kulit buah manggis (Garcinia mangostana L.) memiliki daya antibakteri terhadap Streptococcus sanguinis ATCC 10556
\end{abstract}

Kata kunci: Daya antibakteri, ekstrak etanol kulit buah manggis, Garcinia mangostana L., Streptococcus sanguinis

\section{Antibacterial activity of ethanol extract of mangosteen (Garcinia mangostana L.) peel against Streptococcus sanguinis ATCC 10556}

\begin{abstract}
Introduction: Maintaining dental health through toothbrushing and using mouthwash can prevent the formation of oral biofilms pioneered by Streptococcus sanguinis. The mangosteen (Garcinia mangostana L.) peel is a fruit peel has been known of having antibacterial activity. This study was aimed to determine the antibacterial power of ethanol extract of mangosteen peel (Garcinia Mangostana L.) on the growth of Streptococcus sanguinis ATCC 10556. Methods: Descriptive study was conducted to determine the antibacterial activity of ethanol extract of mangosteen (Garcinia mangostana L.) towards Streptococcus sanguinis ATCC 10556. The population of this study was the mangosteen (Garcinia mangostana L.) peel. The sample used was mangosteen (Garcinia mangostana L.) peel obtained from Bogor Bogor Agricultural University cultivation garden. The inhibition test method was assessed using the disk diffusion method. Results: The largest inhibition zone diameter was found at the concentration of 200,000 ppm with an average diameter of $12.55 \mathrm{~mm}$; followed by the concentration of 100,000 ppm with an average diameter of $11.2 \mathrm{~mm}$; the concentration of 50,000 ppm with an average diameter of 10.3 $\mathrm{mm}$; the concentration of 20,000 ppm with an average diameter of $10.05 \mathrm{~mm}$; concentration of 10,000 ppm with an average diameter of $8.2 \mathrm{~mm}$; concentration of 2,000 ppm with an average diameter of $7.1 \mathrm{~mm}$, and the smallest inhibition zone diameter at the concentration of 1,000 ppm with a diameter of $6.9 \mathrm{~mm}$. Conclusion: Ethanol extract of mangosteen (Garcinia mangostana L.) peel has antibacterial potency towards Streptococcus sanguinis ATCC 10556
\end{abstract}

Keywords: Antibacterial activity, ethanol extract of mangosteen peel, Garcinia mangostana L., Streptococcus sanguinis 


\section{PENDAHULUAN}

Penyakit periodontal merupakan salah satu penyakit gigi dan mulut yang banyak dijumpai pada masyarakat Indonesia. Presentase jaringan periodontal tidak sehat dalam Riskesdas 2013 di Indonesia mencapai $95,21 \%$ dari semua kategori umur. Penyakit periodontal merupakan penyakit yang mengenai jaringan pendukung gigi meliputi gingiva, ligamen periodontal dan tulang alveolar. Penyebab utama penyakit periodontal adalah akumulasi bakteri dalam jumlah yang besar yang terdapat sebagai biofilm oral. ${ }^{1}$

Biofilm dan saliva dapat ditemui berbagai macam bakteri. Salah satunya adalah Streptococcus sanguinis. Streptococcus sanguinis dikenal sebagai bakteri yang pertama berkolonisasi pada permukaan gigi manusia atau sebagai pelopor pada pembentukan biofilm. Bakteri ini dapat ditemui pada sampel biofilm atau saliva. ${ }^{2}$ (Okahasi, et al., 2011). Streptococcus sanguinis adalah bakteri Gram-positif, anaerob fakultatif nonmotile, normal ditemukan pada rongga mulut manusia dan merupakan anggota group Streptococcus viridans. ${ }^{3}$ (Pramesti, 2016). Mekanisme melekatnya bakteri pada permukaan gigi diawali dari kolonisasi bakteri yaitu kemampuan adhesi bakteri pada permukaan inang yang dapat terjadi melalui berbagai mekanisme. Salah satu mekanisme umum meliputi gaya non-spesifik seperti ionik, hidrofobik, van der waals dan ikatan hydrogen antara bakteri dan permukaan inang. ${ }^{4}$

Pencegahan dan pengendalian terhadap pembentukan biofilm harus didasarkan pada upaya pemeliharaan kesehatan mulut yang dilakukan seacara aktif. Pertumbuhan biofilm oral dapat dihambat secara mekanik atau menggunakan bahan kimia (sintetik atau alami) (Eley, 1999). Biofilm tidak dapat dihilangkan hanya dengan berkumur saja, melainkan harus dengan suatu tindakan pembersihan gigi yang baik dan teratur sehingga dapat mencegah dan menghilangkan penumpukan biofilm didalam rongga mulut. Pengendalian biofilm akan berhasil dengan baik bila dilakukan secara aktif, misalnya dengan penyikatan gigi secara rutin dan benar. ${ }^{1}$

Penggunaan obat kumur yang mengandung antiseptik memiliki efek antimikroba terhadap keseluruhan rongga mulut, termasuk daerah yang sulit tercapai saat sikat gigi. Obat kumur antiseptik yang telah banyak digunakan saat ini adalah klorheksidin glukonat, namun klorheksidin masih mempunyai beberapa keterbatasan. Kekurangan klorheksidin yaitu tidak dapat digunakan pada kondisi alergi serta memiliki efek samping berupa peningkatan pewarnaan gigi dan sensasi perubahan rasa pada penggunaan jangka panjang. ${ }^{1}$

Salah satu alternatif yang dapat mengganti penggunaan klorheksidin adalah bahan herbal yang berasal dari kulit manggis yang merupakan obat tradisional. Penggunaan obat tradisional meningkat secara signifikan dalam beberapa tahun terakhir. Pengobatan ini memiliki beberapa kelebihan dibandingkan dengan pengobatan konvensional, seperti keamanan dan keefektifannya telah terbukti secara empirik, efek samping yang lebih sedikit, mudah untuk didapat karena ketersediaannya yang melimpah di alam, biaya yang relatif rendah, teknologi yang digunakan cukup sederhana serta unggul dalam pengobatan penyakit-penyakit kronis yang tidak menular. ${ }^{5}$

Ekstrak etanol kulit buah manggis (Garcinia mangostana L.) dapat digunakan untuk berbagai macam pengobatan antara lain sebagai antioksidan, antivirus, antialergi, anti-inflamasi, antijamur dan antibakteri. Ekstrak etanol kulit buah manggis mengandung senyawa antimikroba seperti flavonoid, tanin, terpenoid, saponin dan xanton. ${ }^{6}$

Hal tersebut di atas, mendorong peneliti untuk melakukan penelitian dengan tujuan penelitian mengetahui daya anti bakteri ekstrak etanol kulit buah manggis (Garcinia Mangostana L.) pada pertumbuhan Streptococcus sanguinis ATCC 10556.

\section{METODE}

Jenis penelitian ini adalah deskriptif, untuk mengetahui uji daya antibakteri ekstrak etanol kulit buah manggis (Garcinia mangostana L.) terhadap Streptococcus sanguinis ATCC 10556. Populasi bahan uji penelitian ini adalah kulit buah manggis (Garcinia mangostana L.) yang ada di Kota Bogor. Sampel yang digunakan adalah kulit buah manggis (Garcinia mangostana $L$.) yang didapat dari kebun budidaya IPB Bogor. Instrumen penelitian yang digunakan pada penelitian ini adalah oese, batang kaca bengkok, cawan petri, labu erlenmeyer, eksikator, sungkup lilin, autoklaf, lemari pendingin, kaca objek, lampu spirtus, mikroskop, pipet ukur, tabung reaksi, jangka sorong dan alat-alat yang biasa digunakan di Laboratorium Mikrobiologi. Sedangkan alat yang digunakan untuk pembuatan ekstrak kulit manggis adalah kertas saring, vacuum rotary evaporator. Waktu penelitian dilakukan pada bulan Maret 2018. Lokasi pembuatan ekstrak etanol kulit buah manggis dilakukan di laboraturium Biofarmaka IPB Bogor dan uji daya antibakteri dilakukan di laboraturium Kimia Universitas Padjadjaran. Analisis data yang dilakukan adalah dengan melakukan uji analitik. Persetujuan etik Nomor : 10/UN6.KEP/EC/2018. 
HASIL

Pengukuran zona hambat ekstrak etanol kulit buah manggis terhadap Streptococcus sanguinis ATCC 10556 dilakukan pada konsentrasi 200.000 ppm, 100.000 ppm, 50.000 ppm, 20.000 ppm, 10.000 ppm, $2.000 \mathrm{ppm}, 1.000 \mathrm{ppm}$. Pengujian zona hambat dengan 2 kali pengulangan pada lempeng agar BHI.

Tabel 1 menunjukan hasil pengukuran zona hambat terhadap ekstrak athanol kulit buah manggis menunjukkan zona hambat yang semakin berkurang seiring berkurangnya konsentrasi. Diameter zona hambat paling besar terdapat pada konsentrasi $200.000 \mathrm{ppm}$ dengan diameter rata-rata $12,55 \mathrm{~mm}$, di ikuti dengan konsentrasi 100.000 ppm dengan diameter rata-rata $11,2 \mathrm{~mm}$, kemudian konsentrasi
50.000 ppm dengan diameter rata-rata $10,3 \mathrm{~mm}$, selanjutnya konsentrasi 20.000 ppm dengan konsentrasi rata-rata $10,05 \mathrm{~mm}$, kosentrasi 10.000 ppm dengan diameter rata-rata $8,2 \mathrm{~mm}$, konsentrasi $2.000 \mathrm{ppm}$ dengan diameter rata-rata 7,1 $\mathrm{mm}$ dan diameter zona hambat paling kecil terdapat pada konsentrasi $1.000 \mathrm{ppm}$ dengan diameter 6,9 mm.

Gambar 1. Zona Hambat Ekstrak Kulit Buah Manggisterhadap Streptococcus sanguinis ATCC 10556. A. Zona hambat ekstrak etanol kulit buah manggis pada konsentrasi 200.000 ppm, 100.000 ppm, 50.000 ppm, 20.000 ppm, klorheksidin 2.000 ppm dan aquades; B. Zona hambat ekstrak etanol kulit buah manggis pada konsentrasi 10.000 ppm, 2.000 ppm, 1.000 ppm, klorheksidin 2.000 ppm dan aquades

\begin{tabular}{cccccccccc}
\hline Rep & $\begin{array}{c}\text { Konsentrasi } \\
\text { (ppm) }\end{array}$ & & & & & & & Kontrol + & Kontrol - \\
\hline & 200,000 & 100,000 & 50,000 & 20,000 & 10,000 & 2,000 & 1,000 & & \\
\hline 1 & 12,4 & 11,3 & 10,2 & 10,1 & 8,2 & 7,1 & 6,9 & 27,3 & 0 \\
2 & 12,7 & 11,1 & 10,4 & 10,0 & $\mathrm{~K}$ & $\mathrm{~K}$ & $\mathrm{~K}$ & 28,1 & 0 \\
Rata-rata & $\mathbf{1 2 , 5 5}$ & $\mathbf{1 1 , 2}$ & $\mathbf{1 0 , 3}$ & $\mathbf{1 0 , 0 5}$ & $\mathbf{8 , 2}$ & $\mathbf{7 , 1}$ & $\mathbf{6 , 9}$ & $\mathbf{2 7 , 5 7}$ & $\mathbf{0}$ \\
\hline
\end{tabular}

\section{PEMBAHASAN}

Hasil penelitian menunjukan bahwa ekstrak etanol kulit buah manggis mempunyai daya antibakteri terhadap Streptococcus sanguinis yaitu dapat dilihat dari terbentuknya zona hambat pada sekitar paper disk. Zona hambat yang terbentuk pada ekstrak kulit manggis merupakan hasil reaksi antara senyawa aktif yang terkandung pada kulit buah manggis seperti flavonoid, tanin, saponin, xanton, terpenoid. Senyawa-senyawa tersebut bereaksi dan bekerja sama menghambat pertumbuhan Streptococcus sanguinis.

Flavonoid merupakan golongan polifenol sehingga memiliki sifat kimia senyawa fenol yaitu bersifatasam. Flavonoid merupakan senyawa polar karena memiliki gugus hidroksil sehingga flavonoid dapat larut dalam air. Flavonoid memiliki mekanisme kerja dalam menghambat pertumbuhan mikroba dengan cara masuk kedalam sel yang menyebabkan terkoagulasi protein pada membran sel sehingga mengakibatkan struktur protein rusak. Ketidakstabilan pada dinding sel dan membran sitoplasma menyebabkan fungsi permeabilitas selektif, fungsi pengangkutan aktif, pengendalian susunan protein dari sel bakteri menjadi terganggu, yang akan berakibat pada hilangnya makromolekul dan ion dari sel, sehingga sel menjadi kehilangan bentuk dan terjadi lisis. ${ }^{7}$
Tanin merupakan senyawa metabolik sekunder pada tumbuhan dan merupakan salah satu grup fenol. Tanin memiliki sifat antimikroba karena memiliki senyawa astrigen. Semyawa astrigen dari tanin diduga dapat mengganggu aktivitas dinding sel dan membran sel bakteri. ${ }^{8}$ (Vanconceles, 2006). Mekanisme tersebut diduga terjadi saat tanin melekat pada dinding sel bakteri kemudian dinding sel tersebut mengalami perubahan morfologi menjadi lebih tebal sehingga terjadi perubahan pada ruang antara dinding sel antara dinding sel dan membrane plasma. Kejadian ini biasa disebut sebagai gangguan permeabilitas sel. Gangguan permeabilitas sel membuat aktivitas sel menjadi terganggu sehingga sel menjadi rapuh dan akhirnya mati. ${ }^{9}$ Tanin dapat mengaktivasi adhesin sel bakteri yang terdapat pada permukaan sel. Senyawa ini juga memiliki bentuk kompleks dengan polisakarida di dinding sel bakteri. ${ }^{10}$

Senyawa saponin merupakan senyawa pada tumbuhan yang dapat menimbulkan busa sehingga mempunyai sifat menyerupai sabun. Saponin diduga melakukan mekanisme antibakteri dengan cara melakukan perlekatan pada lapisan biofilm. Perlekatan ini menyebabkan terjadinya peningkatan tegangan permukaan pada dinding sel bakteri, dinding sel akan mengalami peregangan yang sangat kuat dan kemudian mengakibatkan kerusakan membran sel yang pada akhirnya menyebabkan 
keluarnya berbagai komponen penting untuk pertahanan hidup bakteri seperti protein, asam nukleat dan nukleotida. ${ }^{9}$

Xanton merupakan senyawa kimia dengan manfaat antibakteri yang cukup kuat dan memiliki kemampuan memperlambat replikasi sel pada bakteri. $^{10}$ (Joffrion, 2007) Terpenoid merupakan senyawa fenol yang bersifat lipofilik. Mekanisme kerja terpenoid adalah dengan jalan merusak membrane sel. ${ }^{11}$ (Noorhamdani, 2013).

Zona hambat yang terbentuk disekitar paper disk yang telah ditetesi ekstrak etanol kulit buah manggis, merupakan hasil reaksi senyawa aktif yang terdapat dalam kulit buah manggis.

\section{KESIMPULAN}

Ekstrak etanol kulit buah manggis (Garcinia mangostana $L$ ) memiliki daya antibakteri pada Streptococcus sanguinis ATCC 10556

\section{DAFTAR PUSTAKA}

1. Agrawal, N., Gupta, N., A.K., G., Sharma, V., \& Singh, R. Resaurgence of Phytomedicine Use in Dentistry. American Journal of Phytomedicine and Clinical Therapeutics.; 2014. p.322-333.

2. Okahasi, Nataka, M., Terao, Y., Isoda, R., Sakurai, A., Sumitomo, T., et al. Pili of Oral Streptococcus sanguinis Bind to Salivary Amylase and promote The Biofilm Formation.; 2011. p.148-154.

3. Pramesti, H. T. Streptococcus sanguinis as An Oppotunistic Species in Human Oral Cavity : Adherence, Colonization and Invasion.; 2016. p.45-52.

4. Lamont, R., \& Jenkinson, H. Oral Microbiology at a Glance. UK: Wiley-Blackwell; 2016.

5. WHO. WHO Traditional Medicine Strategy 20142023. Hongkong: WHO Library Cataloguing-inPublication Data; 2013.

6. brahim, M., mariod, A., Mohan, S., Hashim, N., Abdulla, M., Abdelwahab, S., et al. $\alpha$-Mangostin from Garcinia mangostana Linn: an update review of its pharmacological properties. Arabian Journal of Chemistry; 2014.

7. Soeka, Y. Aktivitas Antimikroba FlavonoidGlikosida hasil Sintesis Secara Transglikosilasi Enzimatik.;2007. p.455-464.

8. Vanconceles. Minimum Inhibotory Concentrations of adherene of Punica granatum linn Gel Against S. Mutans.; 2006. p. 227-233.

9. Miguel, M., \& Neves, M. Antibacteria activity of (Punica granatum linn) Against S.Mutans.; 2010.

10. Hayati, E., Jannah, A., \& Fasya, A. Aktivitas Antibakteri Komponen Tanin Ekstrak Daun Belimbing Wuluh (Averrhoa bilimbi) sebagai Pengawet Alami; 2009.

11. Darsana, Besung, \& Mahatmi. Potensi Daun Binabong (Anredera cordifolia) dalam Menghambat Pertumbuhan Bakteri Escherichia coli Secara In Vitro.; 2012

12. Joffrion, D. E. Mangosteen The X-Factor Cross Oaks Chiropractic Health and Pain Relief Cancer; 2007.

13. Noorhamdani. Uji Efektivitas Antibakteri Ekstrak Etanol Kulit Buah Manggis (Garcinia mangostana L.) sebagai Daya Antibakteri terhadap Bakteri A. Baumannii; 2013. 